\title{
EFEK THORACIC MANIPULATION TERHADAP PERUBAHAN LINGKUP GERAK SENDI CERVICAL PADA NON-SPECIFIC NECK PAIN
}

\author{
THE EFFECT OF THORACIC MANIPULATION TO CHANGES RANGE OF MOTION \\ CERVICAL IN NON-SPECIFIC NECK PAIN
}

\author{
Sudaryanto, Syahyu Ratih Fahria Madu \\ Jurusan Fisioterapi Poltekkes Makassar
}

Corresponding Author : sudaryanto@poltekkes-mks.ac.id

\begin{abstract}
ABSTRAK
Latar Belakang: Non-spesific neck pain merupakan nyeri leher yang tidak beradiasi ke lengan atau upper extremitas, dimana nyeri terjadi pada area leher, occipital, dan punggung bagian atas. Pada umumnya nyeri muncul pada akhir keterbatasan ekstensi, lateral fleksi, rotasi, dan fleksi. Metode: Penelitian ini adalah penelitian quasi eksperimen dengan desain randomized control group pre test - post test, bertujuan untuk mengetahui efek penambahan Thoracic Manipulation pada intervensi Ultrasound dan Muscle Energy Technique terhadap peningkatan LGS cervical pada penderita non-spesific neck pain. Sampel penelitian adalah mahasiswa jurusan fisioterapi yang mengeluh non-spesific neck pain (sesuai dengan kriteria inklusi), dan diperoleh jumlah sampel sebanyak 24 orang yang dibagi secara acak ke dalam 2 kelompok. Alat ukur yang digunakan adalah inclinometer. Hasil: Berdasarkan analisis uji paired sample t pada kelompok kontrol dan perlakuan diperoleh nilai $p<0,05$ untuk LGS ekstensi, lateral fleksi, dan rotasi cervical, yang berarti bahwa kelompok kontrol (Ultrasound dan Muscle Energy Technique) dan kelompok perlakuan (Ultrasound, Muscle Energy Technique dan Thoracic Manipulation) dapat memberikan peningkatan LGS cervical yang signifikan. Berdasarkan uji independen sample t, diperoleh nilai p > 0,05 untuk LGS ekstensi, lateral fleksi, dan rotasi cervical, yang berarti tidak ada perbedaan yang signifikan antara Ultrasound, Muscle Energy Technique, Thoracic Manipulation dan Ultrasound, Muscle Energy Technique terhadap peningkatan LGS cervical. Kesimpulan: Kesimpulan penelitian ini adalah penambahan Thoracic Manipulation pada intervensi Ultrasound dan Muscle Energy Technique tidak lebih efektif secara signifikan terhadap peningkatan LGS cervical pada penderita non-spesific neck pain.
\end{abstract}

Kata Kunci : Thoracic Manipulation, LGS Cervical, Non-Spesific Neck Pain

\section{ABSTRACT}

Background: Non-specific neck pain is neck pain that does not radiate to the arm or upper extremity, where pain occurs in the neck, occipital, and upper back. Generally pain appears at the end of limited extension, lateral flexion, rotation, and flexion. Methods: This study was a quasi-experimental study with a pre-test-post-test randomized control group design, aimed to determine the effect of adding Thoracic Manipulation to Ultrasound and Muscle Energy Technique interventions to the increase range of motion cervical in patients with non-specific neck pain. The research sample was physiotherapy students who complained of non-specific neck pain (according to the inclusion criteria), and the total sample was 24 people who were randomly divided into 2 groups. The measuring instrument used is the inclinometer. Results: Based on the analysis of the paired sample $t$ test in the control and treatment groups, $p$ value $<0.05$ was obtained for cervical range of motion extension, lateral flexion, and rotation, which means that the control group (Ultrasound and Muscle Energy Technique) and the treatment group (Ultrasound, Muscle Energy Technique and Thoracic Manipulation) can provide a significant increase range of motion cervical. Based on the independent sample $t$ test, $p$ value $>0.05$ was obtained for cervical range of motion extension, lateral flexion, and rotation, which means that there is no significant difference between Ultrasound, Muscle Energy Technique, Thoracic Manipulation and Ultrasound, Muscle Energy Technique to increase range of motion cervical. Conclusion: The conclusion of this study is that the addition of Thoracic Manipulation to the intervention of Ultrasound and Muscle Energy Technique is not significantly more effective to increasing range of motion cervical in patients with non-specific neck pain

Keywords: Thoracic Manipulation, Range of Motion Cervical, Non-Specific Neck Pain

\section{PENDAHULUAN}

Non-spesific neck pain dianggap menjadi beban ekonomi yang tinggi kedua setiap tahun setelah low back pain bagi para pekerja dan menjadi problem kesehatan umum karena dapat menimbulkan disabilitas pada populasi umum. (Joshua et al, 2007 ;
Rajesh et al, 2014). Sebagian besar pasien yang mengeluh neck pain tergolong kedalam non-spesific neck pain, karena gejalagejalanya yang bersifat non-radikular dan berhubungan dengan faktor postural atau mekanikal (Allan, 2007). 
Sekitar $25 \%$ dari seluruh pasien rawat jalan fisioterapi adalah penderita non-spesific neck pain dan lebih dari $1 / 3$ pasien neck pain akan mengalami perkembangan chronic neck pain dengan gejala lebih dari 6 bulan, serta hampir $1 / 3$ pasien yang pernah mengalami neck pain (Javier et al, 2009).

Penelitian tentang prevelensi nonspesific neck pain di Swedia menunjukkan bahwa $43 \%$ populasi dilaporkan pernah mengalami nyeri leher, dimana lebih banyak terjadi pada perempuan (48\%) dibandingkan laki-laki (38\%) (Guez et al, 2002). Setiap tahun, $27 \%$ sampai $48 \%$ para pekerja mengalami non-spesific neck pain. Nonspesific neck pain biasanya pulih dalam beberapa hari atau minggu, akan tetapi bisa berulang kembali atau bahkan menjadi kronis (Gautam et al, 2014).

Berdasarkan hasil observasi dan pemeriksaan peneliti di Klinik Mabbulosibatang Fisioterapi ditemukan sekitar 32 mahasiswa mengalami nonspesific neck pain dengan keterbatasan gerak yang utama adalah ekstensi, lateral fleksi dan rotasi cervical.

Berdasarkan hasil pemeriksaan fisioterapi oleh peneliti menemukan bahwa sumber gejala dari non-spesific neck pain khususnya berasal dari zygapophyseal joint, otot upper trapezius dan splenius capitis/cervicis pada cervical, dan umumnya menyebabkan keterbatasan gerak rotasi, lateral fleksi dan ekstensi cervical. Pengalaman klinis para ahli menunjukkan bahwa adanya perubahan biomekanik pada cervical akan melibatkan gangguan gerak pada thoracic spine. Adanya hubungan biomekanik antara cervical dan thoracic spine dapat menyebabkan gangguan mobilitas pada cervical mempengaruhi mobilitas thoracic spine, begitu pula sebaliknya gangguan mobilitas thoracic spine dapat menimbulkan berkembangnya non-spesific neck pain (Joshua et al, 2005).

Sejumlah intervensi fisioterapi dapat memberikan manfaat terhadap perbaikan fungsional cervical, antara lain mobilisasi sendi, manipulasi, terapi latihan, massage, dan electrotherapy / thermotherapy. Intervensi manual therapy merupakan salah satu strategi pengobatan yang tepat untuk kasus mechanical neck pain, antara lain mobilisasi dan manipulasi cervical. Namun, beberapa literatur menganjurkan untuk menghindari aplikasi manipulasi cervical terutama pada akhir ROM. Beberapa evidence based saat ini menunjukkan bahwa penggunaan prosedur manual yang diarahkan pada thoracic spine dapat menghasilkan penurunan nyeri dengan cepat. Penelitian Cleland et al (2005) menemukan bahwa thoracic thrust manipulation dapat menghasilkan perbaikan keluhan neck pain dengan cepat dan perbaikan jangka pendek yang berhasil (Javier et al, 2009 ; Joshua et al, 2005 ; Kevin et al, 2011).

Soft tissue manipulation merupakan salah satu metode manual terapi yang efektif untuk kasus spine khususnya non-spesific neck pain. Muscle Energy Technique (MET) merupakan salah satu metode soft tissue osteopathic yang sering digunakan pada kondisi non-spesific neck pain, dimana MET dapat menghasilkan efek post isometric relaxation pada otot yang spasme/tightness sehingga terjadi perbaikan ROM cervical.

Ultrasound (US) memiliki efek terapeutik terhadap problem spasme atau tigth pada otot area cervical, dimana efek US dapat memperbaiki elastisitas dan ekstensibilitas serabut otot yang spasme atau tight. Efek tersebut dapat mengoptimalkan efek terapeutik dari MET dan thoracic maniupulation.

Berdasarkan uraian masalah di atas, maka rumusan masalah penelitian ini adalah apakah penambahan Thoracic manipulation pada Ultrasound dan MET lebih efektif dibandingkan Ultrasound dan MET terhadap perubahan lingkup gerak sendi cervical pada non-specific neck pain ? Dengan demikian, tujuan penelitian ini adalah Untuk mengetahui efektivitas penambahan Thoracic Manipulation pada Ultrasound dan Muscle Energy Technique dibandingkan hanya Ultrasound dan Muscle Energy Technique terhadap perubahan lingkup gerak sendi cervical pada nonspecific neck pain.

\section{METODE \\ Jenis Penelitian}

Jenis penelitian ini adalah penelitian eksperimen dengan randomized pre test post test control group design. Dalam desain penelitian ini, penderita non-specific neck pain sebagai sampel diacak kedalam 2 kelompok yaitu kelompok perlakuan yang diberikan intervensi ultrasound, muscle energy technique dan thoracic manipulation, dan kelompok kontrol yang diberikan 
intervensi ultrasound dan muscle energy technique.

\section{Populasi dan Sampel}

Populasi penelitian ini adalah mahasiswa yang mengalami non-spesific neck pain di Poltekkes Kemenkes Makassar, sedangkan sampel adalah mahasiswa yang mengalami non-spesific neck pain sesuai dengan kriteria inklusi dalam pengambilan sampel. Teknik pengambilan sampel yang digunakan adalah simple random sampling. Besar sampel diperoleh berdasarkan rumus pengambilan sampel yaitu :

$$
n=\frac{2 \sigma^{2}}{\left(\mu_{2}-\mu_{1}\right)^{2}} \int(\alpha, \beta)
$$

Berdasarkan rumus tersebut didapatkan $\mathrm{n}=12,31$ (dibulatkan menjadi 12) sehingga jumlah sampel setiap kelompok sebanyak 12 orang, jadi total sampel sebanyak 24 orang.

Adapun kriteria inklusi yang ditentukan adalah non-spesifik neck pain yang ditandai dengan keterbatasan gerak ekstensi, rotasi, dan lateral fleksi cervical, positif nyeri segmental pada tes PACVP, PAUVP, dan spurling test ekstensi, ditemukan muscle tight pada upper trapezius dan splenius cavitis/cevicis, nyeri leher yang bersifat kronik (diatas 1 bulan), dan bersedia menjalani terapi sebanyak 2 kali terapi. Sedangkan kriteria eksklusi adalah nonspesifik neck pain yang ditandai dengan nyeri radikular, ditemukan instability cervical, memiliki riwayat whiplash injury sebelumnya, dan ada riwayat malignancy.

\section{Prosedur Pengumpulan Data}

Pengumpulan data dilakukan pada awal penelitian sebagai data pre test dan akhir penelitian sebagai data post test. Pengumpulan data didapatkan melalui pengukuran lingkup gerak sendi cervical yang mencakup gerak ekstensi, lateral fleksi dan rotasi cervical dengan menggunakan inclinometer. Adapun prosedur pengukurannya adalah sebagai berikut :

1. Ekstensi Cervical : Sampel dalam posisi duduk. Fisioterapist meletakkan inclinometer di atas kepala, inclinometer harus berada pada angka $0^{\circ}$ sebelum memulai LGS. lalu instruksikan sampel untuk melakukan gerak ekstensi cervical. Gerakan cairan didalam inclinometer menunjukkan derajat LGS yang dicapai.

2. Lateral fleksi cervical : Sampel dalam posisi duduk. Fisioterapist memegang dan meletakkan inclinometer di atas kepala dan inclinometer harus berada pada angka $0^{\circ}$ sebelum memulai LGS, lalu instruksikan sampel untuk melakukan gerak lateral fleksi kiri dan kanan. Gerakan cairan didalam inclinometer menunjukkan derajat LGS yang dicapai.

3. Rotasi cervical : sampel dalam posisi berbaring terlentang, dan posisi cervical berada pada $0^{\circ}$. Inclinometer ditempatkan dan dipertahankan diatas dahi bagian tengah, fisioterapist lalu instruksikan sampel untuk menoleh ke kiri untuk gerakan rotasi cervical kiri dan menoleh ke kanan untuk gerakan rotasi cervical kanan. Gerakan cairan didalam inclinometer menunjukkan derajat LGS yang dicapai.

\section{Prosedur Pelaksanaan Intervensi}

Intervensi yang diberikan pada kelompok perlakuan adalah ultrasound, muscle energy technique dan thoracic manipulation, sedangkan kelompok kontrol adalah ultrasound dan muscle energy technique. Adapun prosedur pelaksanaannya adalah sebagai berikut :

1. Ultrasound

a. Persiapan alat : bersihkan head transducer dengan alkohol, siapkan ultrasound gel.

b. Persiapan pasien : pasien dalam posisi tidur miring (side lying), area upper trapezius bebas dari pakaian

c. Teknik pelaksanaan :

1) Area upper trapezius diolesi gel secukupnya.

2) Setting ultrasound dengan dosis terapi : frekuensi $3 \mathrm{MHz}$, pulse ratio $100 \%$, intensitas $1 \mathrm{w} / \mathrm{cm}^{2}, E R A$ tranducer $5 \mathrm{~cm}$, waktu 5-6 menit. 
3) Tempatkan head transduser pada area upper trapezius yang telah diberi gel

4) Klik Start pada alat kemudian gerakkan transduser secara perlahan didalam area patologis (bisa juga statis).

2. Muscle Energy Technique (MET), terdiri atas MET ekstensi cervical dan MET rotasi + lateral fleksi cervical.

a. MET ekstensi cervical

1) Posisi pasien : tidur terlentang

2) Posisi FT dan tangan FT : FT berada di ujung bed, Satu tangan FT diletakkan dibawah occiput, tangan FT lainnya berada pada dagu pasien.

3) Teknik pelaksanaan : FT mem fleksikan upper cervical pasien melalui dorongan tangan FT di dagu pasien kearah bawah, kemudian sedikit diekstensikan. Pasien diinstruksikan menahan gerakan ke depan dan belakang yang ditimbulkan oleh tangan FT. Kontraksi isometrik yang terjadi dipertahankan selama 6 detik, lalu pasien diminta untuk rileks. Lakukan sebanyak $2-3$ kali. Setelah pasien benar-benar rileks, pasien diminta untuk ekstensi cervical secara perlahan sementara tangan FT membantu kearah ekstensi cervical sampai LGS yang ada dan diulang sampai mencapai LGS normal.

b. MET rotasi + lateral fleksi cervical

1) Posisi pasien : tidur terlentang

2) Posisi FT dan tangan FT : FT berada di ujung bed, tangan kanan FT berada pada segmen artikular yang mengalami gangguan, sedangkan tangan FT lainnya berada di sekitar area temporal.

3) Teknik pelaksanaan : FT meng gerakkan leher pasien kearah lateral fleksi + rotasi sampai titik keterbatasannya. Pasien diins truksikan menahan gerakan ke kesamping kiri - kanan yang ditimbulkan oleh tangan FT di area temporal pasien. Kontraksi isometrik yang terjadi diperta hankan selama 6 detik, lalu pasien diminta untuk rileks. Lakukan sebanyak $2-3$ kali. Setelah pasien benar-benar rileks, pasien diminta untuk rotasi cervical sejauh mungkin sambil tangan FT pada area artikular cervical melakukan upglide sampai LGS yang ada dan diulang sampai mencapai LGS normal.

3. Thoracic Manipulation

a. Posisi pasien : duduk di tepi bed atau di stool/kursi dengan jari-jari saling bertautan di belakang leher

b. Posisi FT dan tangan FT : FT berdiri tepat di belakang pasien, kedua tangan FT memfiksasi regio cervical pasien, dan tempatkan handuk kecil pada upper thoracal sebagai target terapi.

c. Teknik pelaksanaan : pasien diminta untuk relaks dengan bersandar badannya di depan dada FT, kemudian FT menggerakkan thoracal pasien kearah rotasi secara berirama sampai merasa kan relaksasi optimal pada badan pasien. FT melakukan dorongan thrust kecepatan tinggi amplitudo kecil kearah anterior sedikit cranial melalui dada dan handuk kecil pada regio upper thoracal.

\section{Hipotesis Penelitian}

Berdasarkan rumusan masalah maka hipotesis penelitian ini adalah : "Ada perbedaan efektivitas antara Ultrasound, Muscle Energy Technique dan Thoracic Manipulation dengan Ultrasound dan Muscle Energy Technique terhadap perubahan lingkup gerak sendi cervical pada nonspecific neck pain".

\section{Analisis Data}

Dalam menganalisis data penelitian yang telah diperoleh, maka peneliti menggunakan beberapa uji statistik sebagai berikut : 
1. Uji statistik deskriptif, untuk memaparkan karakteristik sampel berdasarkan usia.

2. Uji normalitas data, menggunakan uji Shapiro Wilk untuk mengetahui data berdistribusi normal $(p>0,05)$ atau tidak berdistribusi normal $(p<0,05)$.

3. Uji analisis komparatif (uji hipotesis), hasil uji normalitas data menunjukkan data berdistribusi normal dengan nilai $p>0,05$ untuk data ekstensi, lateral fleksi dan rotasi cervical sehingga digunakan uji statistic parametrik yaitu uji paired $t$ sample dan uji independent $t$ sample.

\section{HASIL PENELITIAN}

Berdasarkan tabel 1. menunjukkan nilai rerata berdasarkan umur, dimana diperoleh nilai rerata $21,25 \pm 1,138$ tahun untuk kelompok kontrol dan nilai rerata $20,75 \pm 0,965$ tahun untuk kelompok perlakuan. Hal ini menunjukkan bahwa ratarata sampel tergolong kedalam usia remaja baik pada kelompok kontrol maupun kelompok perlakuan.

Berdasarkan tabel 2. diperoleh nilai rerata LGS ekstensi, lateral fleksi, dan rotasi cervical pada kelompok kontrol (Ultrasound dan Muscle energy technique) yaitu :

1. LGS ekstensi cervical ; pre test sebesar $47,67 \pm 8,978$ dan post test sebesar $59,50 \pm 6,544$ dengan rerata selisih sebesar $11,83 \pm 2,434$, yang berarti terjadi peningkatan LGS ekstensi cervical dengan rerata sebesar 11,83 setelah intervensi.

2. LGS lateral fleksi cervical : pre test sebesar $38,75 \pm 6,744$ dan post test sebesar 46,92 $\pm 6,626$ dengan rerata selisih sebesar $8,17 \pm 0,118$, yang berarti terjadi peningkatan LGS lateral fleksi cervical dengan rerata sebesar 8,17 setelah intervensi.

3. LGS rotasi cervical : pre test sebesar $58,92 \pm 12,515$ dan post test sebesar $69,83 \pm 6,887$ dengan rerata selisih sebesar $10,91 \pm 5,628$, yang berarti terjadi peningkatan LGS rotasi cervical dengan rerata sebesar 10,91 setelah intervensi.

Pada kelompok perlakuan (Ultrasound, Muscle energy technique, dan Thoracic manipulation) diperoleh nilai rerata LGS ekstensi, lateral fleksi, dan rotasi cervical yaitu :

1. LGS ekstensi cervical : pre test sebesar $40,75 \pm 7,047$ dan post test sebesar $53,92 \pm 8,939$ dengan rerata selisih sebesar $13,17 \pm 1,892$, yang berarti terjadi peningkatan LGS ekstensi cervical dengan rerata sebesar 13,17 setelah intervensi.

2. LGS lateral fleksi cervical : pre test sebesar $33,75 \pm 5,429$ dan post test sebesar $43,67 \pm 3,846$ dengan rerata selisih sebesar $9,92 \pm 1,577$, yang berarti terjadi peningkatan LGS lateral fleksi cervical dengan rerata sebesar 9,92 setelah intervensi.

3. LGS rotasi cervical : pre test sebesar $54,25 \pm 10,146$ dan post test sebesar $66,58 \pm 8,929$ dengan rerata selisih sebesar $12,33 \pm 1,217$, yang berarti terjadi peningkatan LGS rotasi cervical dengan rerata sebesar 12,33 setelah intervensi.

Berdasarkan tabel 3. diperoleh hasil uji paired sample $t$ untuk LGS ekstensi, lateral fleksi, dan rotasi cervical yaitu nilai $p<0,05$ yang berarti bahwa intervensi Ultrasound dan Muscle energy technique dapat memberikan peningkatan LGS ekstensi, lateral fleksi, dan rotasi cervical yang signifikan pada penderita non-spesific neck pain.

Berdasarkan tabel 4. diperoleh hasil uji paired sample $t$ untuk LGS ekstensi, lateral fleksi, dan rotasi cervical yaitu nilai $p<0,05$ yang berarti intervensi Ultrasound, Muscle energy technique, dan Thoracic manipulation dapat memberikan peningkatkan LGS ekstensi, lateral fleksi dan rotasi cervical yang signifikan pada penderita non-spesific neck pain.

Berdasarkan tabel 5. diperoleh hasil uji independent sample $t$ untuk LGS ekstensi, lateral fleksi, dan rotasi cervical yaitu nilai $p$ $>0,05$ yang berarti bahwa tidak ada perbedaan rerata yang signifikan antara kelompok perlakuan (Ultrasound, Muscle energy technique, dan Thoracic manipulation) dan kelompok kontrol (Ultrasound dan Muscle energy technique). Hal ini menunjukkan bahwa Ultrasound, Muscle energy technique, dan Thoracic manipulation tidak lebih efektif secara signifikan dibandingkan dengan Ultrasound dan Muscle energy technique terhadap peningkatan LGS ektensi, lateral fleksi, dan rotasi cervical pada penderita non-spesific neck pain.

Berdasarkan hasil pengujian hipotesis di atas maka dapat disimpulkan bahwa "Penambahan Thoracic manipulation pada Ultrasound dan Muscle Energy Technique tidak lebih efektif secara signifikan dibandingkan dengan Ultrasound dan Muscle Energy Technique saja terhadap 
peningkatan LGS ekstensi, lateral fleksi, dan rotasi cervical pada penderita non-spesific neck pain".

\section{PEMBAHASAN}

Non-spesific neck pain merupakan nyeri leher yang tidak beradiasi ke lengan atau upper extremitas, dimana nyeri tejadi pada area leher, occipital, dan punggung bagian atas. Kondisi ini sangat berhubungan dengan faktor postural atau faktor mekanik (gerakan). Sumber gejala dari non-spesific neck pain khususnya berasal dari zygapophyseal joint atau uncovertebral joint pada cervical, dan umumnya menyebabkan keterbatasan gerak ke segala arah terutama gerak rotasi, lateral fleksi dan ekstensi cervical (de-las-Penas et al, 2007). Pengalaman klinis para ahli menunjukkan bahwa adanya perubahan biomekanik pada cervical akan melibatkan gangguan gerak pada thoracic spine. Adanya hubungan biomekanik antara cervical dan thoracic spine dapat menyebabkan gangguan mobilitas pada cervical yang mempengaruhi mobilitas thoracic spine, begitu pula sebaliknya gangguan mobilitas thoracic spine dapat menimbulkan berkembangnya non-spesific neck pain (Joshua et al, 2005).

Problem keterbatasan gerak ekstensi, lateral fleksi, dan rotasi umumnya ditemukan oleh peneliti pada setiap sampel. Berdasarkan pengamatan dan penelusuran peneliti dari hasil pemeriksaan menunjukkan bahwa problem keterbatasan ekstensi umumnya disebabkan oleh lesi facet joint cervical dan thorakal sedangkan problem keterbatasan rotasi dan lateral fleksi umumnya disebabkan oleh muscle spasm atau muscle tightness pada otot-otot leher terutama splenius capitis, semispinalis cervicis dan upper trapezius.

Peterson dan Bergman (2002), menjelaskan bahwa suatu kejadian atau kondisi seperti postur yang tidak benar, penuaan, cidera akut, kondisi kongenital, semuanya dapat menyebabkan perubahan mekanik sendi atau struktur/fungsi otot sehingga dapat menghasilkan non-spesific neck pain (Roodt, 2009).

Pemberian ultrasound dapat menghasilkan energi kinetik pada jaringan tubuh, dimana molekul-molekul didalam jaringan akan saling bergesekan satu sama lain. Jaringan otot, tendon dan ligament akan mengabsorbsi energi ultrasound sehingga terjadi peningkatan suhu yang digunakan untuk meningkat kan permeabilitas jaringan, akibatnya terjadi peningkatan metabolisme sehing ga mempercepat proses penyembuhan jaringan otot, tendon dan ligament dan menginhibisi aktivitas saraf simpatis sehingga menghasilkan penurunan ten sion pada jaringan (Susan et al, 2012). Hal ini akan memudahkan penerapan Muscle Energi Technihque dan Thoracic manipulation dalam meningkatkan LGS.

Pemberian Muscle Energi Technique setelah Ultrasound memberikan efek PIR (post isometric relaxasi) dan RI (reciprocal inhibition) yang dapat menghasilkan peningkatan LGS ekstensi, lateral fleksi, dan rotasi cervical. MET menggunakan prinsip PIR dalam menurunkan tonus otot, dimana mekanisme kerjanya yakni kontraksi isometrik otot yang tight/ spasme saat dilakukan MET akan mengaktivasi golgi tendon organ (GTO), GTO yang teraktivasi akan mengaktifkan interneuron pada Medulla Spinalis yang dapat berfungsi sebagai inhibisi pada saraf motorik sehingga efek tersebut dapat menyebabkan penurunan tonus atau ketegangan otot. Efek PIR dan RI dapat menghasilkan refleks relaksasi dan perubahan otot terhadap toleransi stretch. Kemudian, efek $R I$ yang dihasilkan oleh Muscle Energy Technique dengan mengaktivasi kontraksi otot antagonist (otot yang sehat) dapat menginhibisi tonus otot agonis yang spasme/tightness sehingga akan menun jukkan penurunan tonus dengan cepat setelah kontraksi (Chaitow, 2006). Terjadinya penurunan tonus otot yang dihasilkan oleh Muscle Energy Technique dapat meningkatkan lingkup gerak sendi.

Pengalaman klinis para ahli menunjukkan bahwa adanya perubahan biomekanik pada cervical akan melibatkan gangguan gerak pada thoracic spine. Aplikasi thoracic spine berdasarkan penelitian diatas menunjukkan bahwa manipulasi dapat menghasilkan efek mekanikal pada sendi sehingga terjadi perbaikan LGS sendi (Kenneth, 2016).

Penambahan Thoracic manipulation dapat menghasilkan gapping (celah/ pemisahan) pada permukaan facet joint thoracal sehingga menunjukkan adanya perbaikan lingkup gerak sendi yang cepat dan penurunan nyeri gerak. Thoracic manipulation dapat menghasilkan efek mekanikal pada sendi sehingga terjadi perbaikan LGS sendi (Kenneth, 2016).

Pada penelitian Kwan et al (2016), menemukan bahwa pemberian Thoracic manipulation dapat meningkatkan LGS 
secara signifikan dengan nilai $p<0,05$ dengan rata-rata peningkatan sebesar 15.5 \pm 5.8 (Kwan et al 2016).

Beberapa penelitian sebelumnya melaporkan bahwa pemberian muscle energy technique dapat memberikan peningkatan LGS pada penderita nonspesific neck pain. Penelitian Kruva et al (2018) menemukan bahwa pemberian Muscle energy technique dapat meningkatkan LGS secara signifikan dengan nilai $\mathrm{p}<0,05$ dan rata-rata peningkatan sebesar 53.42 \pm 3.3 (Krupa et al 2015). Beberapa penelitian juga mengemukakan bahwa pemberian dengan kombinasi elektro terapi, dapat memberikan hasil yang lebih efektif terhadap peningkatan LGS.

Perbedaan kedua kelompok sampel terletak pada penambahan Thoracic manipulation pada intervensi ultrasound dan muscle energy technique. Seperti yang telah dijelaskan diatas bahwa thoracic manipulation dapat menghasilkan gapping (celah/ pemisahan) pada permukaan facet joint thoracal sehingga menunjukkan adanya perbaikan lingkup gerak sendi yang cepat dan penurunan nyeri gerak setelah diberikan intervensi Ultrasound dan Muscle Energy Technique. Sedangkan kelompok kontrol yang tanpa Thoracic manipulation juga menghasilkan perbaikan lingkup gerak sendi dan penurunan nyeri gerak yang signifikan melalui efek dari Ultrasound dan Muscle Energy Technique.

Penelitian sebelumnya oleh Kwan et al (2016), menemukan bahwa penambahan Thoracic manipulation pada intervensi SNAGs dapat meningkatkan LGS secara signifikan dengan nilai $p<0,05$ dan rata-rata peningkatan sebesar $15.5 \pm 5.8$.

Meskipun demikian, hasil penelitian ini berbeda dengan penelitian sebelum nya. Hal ini mungkin disebabkan oleh teknik Muscle Energy Technique yang menghasilkan efek peningkatan lingkup gerak sendi yang sangat besar sehingga dapat mencapai lingkup gerak sendi mendekati normal.

\section{KESIMPULAN}

1. Intervensi Ultrasound, Mupscle Energy Technique dan Thoracic Manipulation dapat meningkatkan LGS cervical pada penderita non-spesific neck pain.

2. Intervensi Ultrasound dan Muscle Energy Technique dapat meningkat kan LGS cervical pada penderita non-spesific neck pain.
3. Penambahan Thoracic Manipulation pada intervensi Ultrasound dan Muscle Energy Technique tidak memberikan efek yang lebih besar secara signifikan daripada hanya Ultrasound dan Muscle Energy Technique terhadap peningkatan LGS cervical pada penderita non-spesific neck pain.

\section{DAFTAR PUSTAKA}

Binder, Allan.I. 2010. Clinical Review Cervical spondylosis and neck pain. Stevenage, Hertfordshire: Vol 334.

Calliet, R. 2011. Neck and Arm Pain : Pain Series. Third Edition, Philadelphia: F.A. Davis Company.

Chaitow, L. 2012. Muscle Energy Technique. Third Edition. Edinburgh: Churchill Livingstone.

Cross, Kevin.Mchris., Chris, Kuenze., Grindstaff, Terry., Hertel Jay. 2011. Thoracic Spine Thrust Manipulation Improves Pain, Range of Motion, and Self-Reported Function in Patients With Mechanical Neck Pain: A Systematic Review. Journal of Orthopaedic \& Sports Physical Therapy ; vol 41 :number 9.

De-las-Penas, C.F., del-Cerro, L.P., Blanco, C.R., Conesa, A.G., Page, J.C., Miangolarra. 2014. Changes in Neck Pain and Active Range of Motion After A Single Thoracic Spine Manipulation in Subjects Presenting with Mechanical Neck Pain : A Case Series. Journal of Manipulative and Physiological Therapeutics; Vol 30: Number 4.

Douglas AB, Bope ET. Evaluation and treatment of posterior neck pain in family practice. JABFP 2014; 17: 1322.

Gautam, Rajesh., Dhamija, Jagdeep.Kaur., Amit,Puri. 2014. Comparison of Maitland and Mulligan Mobilization in Improving Neck Pain, ROM and Disability. International Journal of Physiotherapy and Research ; Vol 2(3) : 482-87.

Gonzales, Javier.Iglesias., De-las-Penas, C.F., Joshua, A.Cleland Francisco, Albur querque-Sendı., Luis, Palomeque-del-Cerro., Roberto Me'ndez-Sa' nchez. 2011. Inclusion of thoracic spine thrust manipulation into an electro-therapy/thermal program for the management of patients with acute mechanical neck pain: $A$ randomized 
clinical trial. Manual Therapy ; Vol 14 : 306-313.

Green, B.N., Dunn, A.S., Pearce, S.M., Johnson, C.D. 2014. Conservative management of uncomplicated mechanical neck pain in a military aviator. The Journal of the Canadian Chiropractic Association; Vol. 8: 676680.

Guez M, Hildingsson C, Nilsson M, Toolanen G: The Prevalence of Neck pain: a Population-Based Study Northern Sweden, Departement of Orthopaedics University Hospital, Umea, Sweden, 2012.

Hamill, J., Knutzen, M.k., Derrick, R.T. 2015. Biomechanical Basis of Human Movement. Fourt Edition. Philadelphia : Lippincott Williams \& Wilkins.

Hertling, D., Kessler, R.M. 2014. Management of Common Musculoskeletal Disorders. Fourth Edition. Philadelphia : Liappincott Williams \& Wilkins.

Joshua, A.Cleland., Childs, D.John., Fritz, M. Julie., Whitman, M. Julie., Eberhart, L.Sarah. 2011. Developement of a Clinical Prediction Rule for Guiding Treatment of Subgroup of Patient Education. Physical Therappy ; Vol 87, Issue $1: 9-23$.

Kisner, C., Colby, L.A. 2012. Therapeutic Exercise Foundations And Techniques. Fifth Edition. Philadelphia: F.A. Davis Company.

Kwan-Woo Lee, Won-Ho Kim. 2016. Effect of thoracic manipulation and deep Craniocervic al flexor training on pain, mobility, strength, and disability of the neck of patients with chronic nonspecific neck pain:a randomized clinical trial. SPTS. Republic Of Korea ; J. Phys. Ther. Sci. 28: 175-180, 2016

Krupa D. Tank, Prachi Choksi, Priyanka Makwana. 2018. To study the effect of muscle energy technique versus mulligan snags on pain, range of motion and functional disability for individuals with mechanical neck pain: a comparative study. International Journal of Physiotherapy and Research,Int J Physiother Res 2018, Vol 6(1):2582-87.

Mahajan, R., Kataria, C., Bansal, K. 2012. Comparative Effectiveness of Muscle Energy Technique and Static Stretching for Treatment of Subacute
Mechanical Neck Pain. International Journal of Health and Rehabilitation Sciences; Vol 1: Number 1.

Maitland, G.D., 2012. Vertebral Manipulation. Fifth Edition. Oxford : ButterworthHeinemann.

McKenzie, R., Kubey, C. 2012. 7 Steps To A Pain-Free Life. New York: Penguin Group Inc.

McKenzie, R., May, S. 2012. The Cervical \& Thoracic Spine Mechanical Diagnosis \& Therapy. Volume One. New Zealand: Spinal Publications.

Nancy B, and William D,. 2014. Joint Range of Motion and Muscle Length Testing. Philadelphia : Saunders.

Nicholas, A.S., and Nicholas E.A. 2012. Atlas of Osteopathic Technique. Second Edition. Philadelphia : Lippincott Williams and Wilkins.

Norkin, C.Cynthia., White, Joyce. 2011. Measurement of Joint Motion. Fourth Edition. United State of America : F.A Davis Company.

Olson, A.Kenneth. 2016. Manual Physical Therapy of The Spine. Second Edition. United State of America : Elsevier.

Pamela, K.Levangie., Norkin, C.Cynthia. 2015. Joint Structure and function. United State of America : F.A Davis Company.

Roodt, M.L.E. 2016. A Comparative Study of Three Different Types of Manual Therapy Techniques In The Management of Chronic Mechanical Neck Pain. (dissertation). South Africa: Faculty of Health, Durban University of Technology.

Steve, 2015. Mechanical Neck Pain is also called Axial Neck Pain. Available from www.necksolutions.com/

mechanicalneck-pain.html, diakses tanggal 12 Februari 2018.

Susan, L.Michlovitz., James, W.Bellew., Thomas, P.Nolan Jr. 2012. Modalities for Theurapeutic Intervention. Fifth Edition. United State of America : F.A Davis Company.

Sopiyuddin, MD. 2009. Besar Sampel dan Cara Pengambilan Sampel Dalam Penelitian Kedokteran dan Kesehatan. Jakarta : Salemba Medika.

Wiliam E.P. 2013. Therapeutic Modalities. Fifth Edition. New York: Mc Graw Hill.

Wise, H.Christopher. 2015. Orthopaedic Manual Physical Therapy. United State of America : F.A Davis Company. 
Tabel 1

Rerata Sampel berdasarkan umur di Klinik Mabbulosibatang

\begin{tabular}{ccccc}
\hline \multirow{2}{*}{ Karakteristik sampel } & \multicolumn{2}{c}{ Klp Kontrol } & \multicolumn{2}{c}{ Klp Perlakuan } \\
\cline { 2 - 5 } & Rerata & SB & Rerata & SB \\
\hline Umur (thn) & 21,25 & 1,14 & 20,75 & 0,97 \\
\hline
\end{tabular}

Tabel 2.

Rerata LGS berdasarkan nilai pre test, post test, dan selisih

\begin{tabular}{lccc}
\hline \multirow{2}{*}{ Klp Sampel } & \multicolumn{3}{c}{ Rerata dan Simpang Baku } \\
\cline { 2 - 4 } & Pre test & Post test & Selisih \\
\hline Klp Kontrol : & & & \\
\hline Extensi & $47,67 \pm 8,98$ & $59,50 \pm 6,54$ & $11,83 \pm 2,43$ \\
Lateral fleksi & $38,75 \pm 6,74$ & $46,92 \pm 6,63$ & $8,17 \pm 0,12$ \\
Rotasi & $58,92 \pm 12,52$ & $69,83 \pm 6,89$ & $10,91 \pm 5,63$ \\
\hline Klp Perlakuan : & & & \\
\hline Extensi & $40,75 \pm 7,05$ & $53,92 \pm 8,94$ & $13,17 \pm 1,89$ \\
Lateral fleksi & $33,75 \pm 5,43$ & $43,67 \pm 3,85$ & $9,92 \pm 1,58$ \\
Rotasi & $54,25 \pm 10,15$ & $66,58 \pm 8,93$ & $12,33 \pm 1,22$ \\
\hline
\end{tabular}

Tabel 3.

Uji beda rerata LGS sebelum dan sesudah intervensi pada kelompok kontrol

\begin{tabular}{|c|c|c|c|c|}
\hline Klp Data & Pre test & Post test & $\mathrm{t}$ & $\mathrm{p}$ \\
\hline \multicolumn{5}{|l|}{ Extensi } \\
\hline Rerata & 47,67 & 59,50 & \multirow{2}{*}{$-4,75$} & \multirow{2}{*}{0,001} \\
\hline Simpang baku & 8,98 & 6,54 & & \\
\hline \multicolumn{5}{|l|}{ Lateral fleksi } \\
\hline Rerata & 38,75 & 46,92 & \multirow{2}{*}{$-6,25$} & \multirow{2}{*}{0,000} \\
\hline Simpang baku & 6,74 & 6,63 & & \\
\hline \multicolumn{5}{|l|}{ Rotaasi } \\
\hline Rerata & 58,92 & 69,83 & \multirow{2}{*}{$-5,86$} & \multirow{2}{*}{0,000} \\
\hline Simpang baku & 12,52 & 6,89 & & \\
\hline
\end{tabular}

Tabel 4.

Uji beda rerata LGS sebelum dan sesudah intervensi pada kelompok perlakuan

\begin{tabular}{|c|c|c|c|c|}
\hline Klp Data & Pre test & Post test & $\mathrm{t}$ & $p$ \\
\hline \multicolumn{5}{|l|}{ Extensi } \\
\hline Rerata & 40,75 & 53,92 & \multirow{2}{*}{$-5,86$} & \multirow{2}{*}{0,000} \\
\hline Simpang baku & 7,05 & 8,94 & & \\
\hline \multicolumn{5}{|l|}{ Lateral fleksi } \\
\hline Rerata & 33,75 & 43,67 & \multirow{2}{*}{$-8,77$} & \multirow{2}{*}{0,000} \\
\hline Simpang baku & 5,43 & 3,85 & & \\
\hline \multicolumn{5}{|l|}{ Rotaasi } \\
\hline Rerata & 54,25 & 66,58 & \multirow{2}{*}{$-5,29$} & \multirow{2}{*}{0,000} \\
\hline Simpang baku & 10,15 & 8,93 & & \\
\hline
\end{tabular}


Tabel 5.

Uji beda rerata post test LGS antara kelompok kontrol dan kelompok perlakuan

\begin{tabular}{lcccc}
\hline \multicolumn{1}{c}{ Klp Data } & Kontrol & Perla kuan & $\mathrm{t}$ & $\mathrm{p}$ \\
\hline Extensi & & & & \\
\hline Rerata & 53,92 & 59,50 & $-1,75$ & 0,95 \\
Simpang baku & 6,54 & 8,94 & & \\
\hline Lateral fleksi & & & $-1,47$ & 0,16 \\
\hline Rerata & 46,92 & 43,67 & & \\
Simpang baku & 6,63 & 3,85 & & \multirow{2}{*}{0,33} \\
\hline Rotasi & & & & \\
\hline Rerata & 69,83 & 66,58 & & \\
Simpang baku & 8,93 & 6,89 & &
\end{tabular}

